\title{
In this Issue of KRITIKE: An Online Journal of Philosophy
}

Paolo A. Bolaños

T his seventh edition marks the third year of existence of KRITIKE: An Online Journal of Philosophy. As such, the edition demonstrates the maturity of the journal. As we welcome contributions from various philosophical persuasions in varying styles, the face and scope of the journal itself become variegated. In this issue, we are introducing the Dialogos section-wherein we feature two pairs of essays in debate cum dialogue form. In the Articles section, we bring you ten essays in Critical Theory, Aesthetics, Existentialism, Literary Criticism, Linguistics, and the exegeses of Greek texts. In addition to these excellently written essays are a couple of Book Reviews.

The Latin "dialogos," from which the English word "dialogue" was derived, aptly characterizes the thrust of the journal's latest section. In this first installment of Dialogos, Chris Calvert-Minor's diagnosis of the celebrated Michel Foucault's "incongruence" in "Archeology and Humanism: An Incongruent Foucault" is critically examined by Brian Lightbody. CalvertMinor argues that there is an existing tension in "Foucault's writings concerning his alleged anti-humanism" in the sense that Foucault's philosophy has a secret affair with humanism, weakening his post-structuralist tendency. Meanwhile, Lightbody, in "Genealogy and Subjectivity: An Incoherent Foucault (A Response to Calvert-Minor)," avers that Calver-Minor is mistaken since "Foucault is not working with a tacit conception of humanity," but rather, he is "working with a tacit conception of subjectivity." The second dialogical exchange is between F. P. A. Demeterio and Paolo A. Bolaños, whose essays are written in the Filipino language. "Ang Demokratikong Sistema at ang mga Modelo ng Pamumuno sa Pilipinas" was read before the Filipino Department of De La Salle University-Manila as Demeterio's Don Francisco Ortigas, Sr. Professorial Lecture. In this piece, Demeterio, via cognitive anthropology, surveys the historico-political development of "models of governance" (mga modelo ng pamumuno) in the Philippines. The essay traces such development from the pre-Hispanic era to the present "democratic" system of the Philippines; Max Weber's concept of democratic leadership informs the trajectory of Demeterio's paper. Bolaños, for his part, describes Demeterio's study as an expression and inscription of hope and failure, that is to say, by revisiting the development of governance in the Philippines, Demeterio, according to Bolaños, maps out normative limitations and possibilities for the Filipino nation. 


\section{ii IN THIS ISSUE OF KRITIKE}

The first essay under the Articles section is Jeffry V. Ocay's "Technology, Technological Domination, and the Great Refusal: Marcuse's Critique of the Advanced Industrial Society." Ocay notes at the outset of his paper that Marcuse's work is driven by the recurring theme of "emancipation"- the attempt to liberate men from social injustices. Such notion of emancipation, however, presupposes the diagnosis of socio-political pathologies and Ocay shows us that Marcuse locates such pathologies in "technological domination." The point of Ocay's essay is not to downplay the role of technology in our lives, especially its positive benefits, but, rather, to highlight the fact that technology can also be a "tool for emancipation." The emancipatory potential of technology is gleaned from the interplay between desire (Eros), aesthetics, and politics-in other words, the interplay between human, all too human expressions. One perceives Marcuse echoing Heidegger: that technology is an extension of humanity. In "Between Collingwood's and Croce's Art-Theories: A Comparative Study," Raymundo R. Pavo wonders whether Collingwood may have only extended the theory of art of the Italian philosopher Benedetto Croce, due to the former's expressed gratitude to the latter's influence. Pavo's purpose is, therefore, to "tease out a crucial difference between their standpoints" in order to justify that Collingwood's theory of art is unique. Despite the overwhelming similarities between Collingwood and Croce, Pavo maintains that "Collingwood's originality in so far as we interpret it against the backdrop of Croce's art-theory, is situated in his stance on the conditions that provide and sustain the life of art."

Rufus Duits points out, in "The Existential Turn: Reappraising Being and Time's Overcoming of Metaphysics," that despite the transcendental agenda and practical import of Heidegger's Being and Time, one would find neither a clear "theory of categories" nor a "theory of the will." According to Duits, it is perhaps possible to clarify this issue if one evades the vexed question regarding the so called Kehre in Heiddeger's career, and to instead read Heidegger "in light of the task of overcoming metaphysics." Duits emphasizes that understanding the "being-historical role of Being and Time" will allow us to construe Heidegger's project as an overcoming of metaphysics-what Duits refers to as the "existential overcoming of metaphysics." Moreover, Duits also wants to revisit and reinstall the now often neglected reorganization of philosophical concepts in Being and Time. For his part, Thomas Kochalumchuvattil exposes the crisis of identity in Africa. Kochalumchuvattil observes that the socio-political problems that have plagued African countries (ethnic cleansing, political turmoil, the rise of HIV/AIDS cases) profoundly contributes to the oppression of the "self," that is to say, the oppression of subjectivity, of individual freedom. Kochalumchuvattil argues, however, that the development of individual subjectivity lies in a kind of social consciousness that is essentially woven in the fabric of African culture. Kochalumchuvattil examines the potentialities of Ubuntu philosophy in the recovery of African identity; Ubuntu "is a unifying vision or worldview" grounded in a deep awareness of the humanity of others and through which one's humanity or identity is also recognized. Ubuntu resembles the Hegelian notion of self- 


\section{P. BOLAÑOS iii}

reflexivity: one can only become conscious of oneself when one becomes conscious of other consciousnesses, that is, of other people. Nevertheless, Ubuntu, intimates Kochalumchuvattil, should be harnessed together with a more robust sense of individuation so as not to result to communalism; as such, the Kierkegaardian call for subjectivity is invoked as a guiding framework that could possibly offset communalism.

"No Name: Paul Celan's Poetics of Naming" is Antti Eemeli Salminen's attempt to expose how poetry, such as Celan's, is able to "form a critique of naming," in particular, a critique of how philosophical concepts undergird name-giving in poetic texts. Salminen's paper discusses the dialectics between "anonymity" and "naming." The essay ends with the contention that Celan's poetry-far from resisting the gesture of naming-unnames, denames, and anonymizes "in the quest to say what there is as such, without claims about fixed identities and kinships." Celan's poetry is, par excellence, a deconstruction of linguistic fixity and a reinvention of meaning(s) sans the commitment to any single name. Meanwhile, Nicole Note reflects on the social relevance of meaningfulness. Note first summarizes the existing views on meaningfulness: religious, meaningfulness as a matter of choice, and meaningfulness grounded in standard objective values. The remaining of the essay is an exploration of the third view on meaningfulness, one which we could perhaps understand as meaningfulness based on normative practices of society. According to Note, the recognition of "horizons," may that be the social sphere or nature, provides a more concrete, and therefore meaningful, relation between people and their environment - there is the possibility of "touching" the horizon. Note writes: “. . . if people have a flattened worldview, if they are cut off from this wider horizon and if they relate to the world only in instrumental terms, the result will be a loss of meaning." Sikander Jamil's "Frege: The Theory of Meaning Concerning Proper Names" tackles the philosophical issues of "meaning" and "naming" from the standpoint of Analytic Philosophy. Jamil's essay is a systematic study of the ideas of one of the forerunners of the Analytic tradition, the German mathematician and logician Friedrich Ludwig Gottlob Frege, pointing out that Frege is the first to have systematically dealt with the problem of meaning; as such, Frege is noted to be the first to have laid down an Analytic study of language, wherein meaning is seen as a result of a sentence's constitutive parts. Jamil reconstructs Frege's theory of meaning and proper names, respectively. Central to Jamil's reconstruction are Michael Dummett's commentaries on the

philosophy of Frege. Jamil also devotes a section to J. L. Austin and John Searle whose theories of "speech acts" could serve as possible revisionist readings of Frege.

The last two essays under the Articles section are compelling exegeses of Greek texts. The essays are studies, respectively, of the two philosophical giants of Ancient Greece, Plato and Aristotle. David W. Bollert revisits the starting point of Western philosophy_-"wonder"—and figures out how wonder plays out in the dialogues of Plato, specifically how the sense of wonder is evoked in Socrates and his interlocutors. Via an exegetical treatment 


\section{iv IN THIS ISSUE OF KRITIKE}

of the Phaedrus, Symposium, Phaedo, Crito, Charmides, and the Theaetetus, Bollert demonstrates that the personas of these dialogues, by being "wonderers" or philosophers, they are also "true wonders in themselves." What this means, for Bollert, is that inasmuch as wonder is the beginning of the love of wisdom, the human being is the only being who wonders and it is through the lenses of the human being - the one who loves wisdom — that the wonders of reality, metaphysical or otherwise, are disclosed. One's love for philosophy, according to Aristotle, is a kind of love that nurtures friendship - this is the overarching temperament of Efren A. Alverio's "Other Selves." Alverio compares two arguments from Aristotle's Nichomachean Ethics on friendship, between "the happy person needs friends" and "a person who is to be happy needs good friends." Is happiness a precondition for friendship or is friendship a precondition for happiness? - this is perhaps the basic question of Alverio. Ultimately, Alverio tries to show us that "happiness" and "friendship" are inextricably related.

Under the Book Reviews section, two recent monographs on two influential European philosophers are reviewed. Lee Braver's Heidegger's Later Writings: A Readers Guide (2009) is reviewed by Paul J. Ennis. This reader's handbook, Ennis observes, is an examination of Heidegger's output after the publication of Being and Time in 1927. As such, Braver contributes to the ongoing debate regarding Heidegger's alleged Kehre by providing an overview of the significant themes that preoccupied Heidegger's later thought. Ennis points out that Braver's Heidegger's Later Writings would prove useful to beginning students in Heideggerian thought, as it provides relevant readings from key texts and a carefully prepared bibliography. Another strength of Heidegger's Later Writings is its authors very admirable ability to flesh out Heideggerian themes without succumbing to the jargon of Heideggerian scholarship. Finally, Kristoffer A. Bolaños commends The Political Philosophy of Michel Foucault by Mark G.E. Kelly for its delivery of a promising exposition of what can be construed as a "political philosophy" in the works of Foucault, despite the fact that Foucault himself resisted any theoretical systematization. The strength of Kelly's book, according to the reviewer, is its "account of the links and connections of themes ranging from archeology and genealogy, to power, to resistance and the way they recur in Foucault's books."

I would like to end this editorial by acknowledging the following people for their support and help in the completion of this issue: Dr. Mark Calano (Ateneo de Manila University), Dr. Ryan Urbano (University of San Carlos), Dr. Jove Jim Aguas (University of Santo Tomas), Dr. F. P. A. Demeterio (De La Salle University-Manila), and Ms. Tracy Ann Llanera (University of Santo Tomas).

Finally, on behalf of the KRTIKE Editorial Board, I am pleased to announce and welcome two new Associate Editors of the journal: Mr. Peter Emmanuel Mara, M.A. (University of Santo Tomas) and Mr. Dean Edward Mejos, M.A. (University of Asia and the Pacific). 